\title{
The Impact of Information and Communication Technology Utilisation on Firm Performance: A Case Study of Women Entrepreneurs
}

\author{
RAHMAH ISMAIL \\ NOR AINI HAJI IDRIS \\ Faculty of Economics and Business \\ Universiti Kebangsaan Malaysia
}

ABSTRACT

Rapid economic development and globalisation make Information and Communication Technology (ICT) become more important as media of production, marketing, and sourcing information. In this era, the level of computerisation is viewed as crucial for the development of industries. Enterprises that are lagging in the ICT facilities are regarded as out-dated and not progressing. Women entrepreneurs are - always seen as lagging behind and there is a wide digital divide among them, hence different levels of performance prevails. This paper attempts to examine this issue through focusing on factors that influence level of ICT utilisation in women owned enterprises and how far this will affect their firm performance. In this paper performance is measured by percentage sales, percentage export, value of sales, and profit earned by the firms. The analysis is based on 200 women entrepreneurs surveyed in 2004 in the Klang Valley. They are involved in various types of manufacturing and services sub-sectors. The study found that the level of ICT utilisation is significantly determined by the entrepreneur's level of education,

- period of firm establishment, and firm size. It was also found that capital and labour are the two most important determinants of total sales. Other factors that significantly determine total sales are firm size, ICT workers, Internet usage, and computer usage in the production and accounting management.

\footnotetext{
ABSTRAK

Pembangunan pesat ekonomi dan globalisasi menjadikan ICT semakin penting sebagai alat pengeluaran, pemasaran dan sumber maklumat. Dalam era ini, tahap penggunaan komputer dianggap penting untuk pembangunan industri. Perusahaan yang kurang fokus dan ketinggalan di dalam penyediaan kemudahan komputer dianggap tidak membangun. Jurang digital dialami oleh kebanyakan usahawan wanita sehingga menjejaskan prestasi perniagaan. Artikel ini cuba membincangkan isu jurang digital dalam kalangan usahawan wanita dengan melihat faktor-faktor yang mempengaruhi tahap penggunaan ICT dan sejauh mana ianya mempengaruhi prestasi firma. Prestasi dalam perbincangan artikel ini diukur berdasarkan peratus jualan, peratus eksport dan nilai jualan serta untung yang diperolehi firma. Analisis dibuat berdasarkan hasil kajian yang dilakukan pada 2004 terhadap 200 sampel usahawan wanita di sekitar Lembah Klang. Mereka terlibat di dalam pelbagai jenis perniagaan dalam subsektor pembuatan dan perkhidmatan. Hasil kajian mendapati tahap penggunaan ICT dipengaruhi oleh tahap pendidikan usahawan, jangka masa penubuhan firma dan saiz firma. Di samping itu, modal dan buruh merupakan faktor penting yang mempengaruhi jumlah jualan diikuti faktor-faktor lain termasuk pekerja ICT, penggunaan internet dan penggunaan komputer di dalam pengurusan pengeluaran dan akaun.
} 


\section{INTRODUCTION}

Information and Communication Technology (ICT) has changed the structure of opportunities in many postindustrial societies all over the world including Malaysia. It offers relatively cheap and efficient services, promises in the delivery of basic services like education and health information to far-flung regions, and it may help to integrate the concerns of a developing society in the international arena (Pippa, 2000). However, before the potential benefits of ICT an flow to developing countries, basic access is required. According to the United Nations (2000), the gains in productivity produced by the new technology may widen differences in economic growth between the most affluent ations and those that lack the skills, resources, and information to invest in the information ociety. As a result, poorer societies can become increasingly marginalised at the periphery of communication networks. Within countries, the uneven diffusion of ICT utilisation appears along familiar lines of social inequality such as socio-economic status, gender, age, geographic location and ethnicity.

The application of information and knowledge is emerging as a new determinant of competitiveness for firms and countries. Economic success in this new and rapidly changing environment however, will require considerable agility and adaptability. Those countries, sectors, organisations and individuals that can adapt to this environment will be far better off than those that cannot or will not adapt. The adoption and - utilisation of ICT require enough skilled workers Who are related to that technology. ICT skills constraints have an indirect negative impact on firm performance as a result of the restrictions that uch skill deficiencies place in ICT adoption and n the intensity of use of ICT (Forth \& Mason, 2004).

Nowadays firms must invest in ICT to be more efficient and competitive. In principle, ICT investment should help early-adopting firms to achieve higher levels of performance through improving the efficiency of various sections or by facilitating more rapid monitoring of trends in customer demand and communications with suppliers of key components and services. However, the short term impact of ICT investments on firm-level performance may be mild and even negative due to the time and resources needed to develop complementary production inputs (Helpman \& Trajtenberg, 1998). In order to develop complementary inputs, it may need a long time lag to get the desired impact of ICT investment on firm performance.

Many firms need to pass through periods of experimentation and learning, investing in the adaptation or development of software, the implementation of appropriate new modes of work organisation and the development of new products and services (Forth \& Mason, 2004). Bresnahan, M., Brynjolfsson and Hitt (2002) suggested that organisational investments in asset, which are complementary to information and communication technologies (ICTs) may contribute more to raising the relative demand for skilled labour than the diffusion of ICTs themselves.

Forth and Mason (2004) studied ICT adoption and utilisation by firms in the United Kingdom. More specifically, they measured the impact of ICT adoption and utilisation on firm performance, i.e total sales. They found that the extent of ICT adoption and the intensity of use of connectivity technologies were positively and significantly related to enterprise size groups. Furthermore, this study found that the intensity of computer use tended to be higher in small and medium sized enterprises than in larger organisations. Single-site enterprises were significantly less likely to make intensive use of connectivity technologies and multinational firms and were positively and significantly related to both ICT adoption and utilisation.

The same study also found that ICT skill deficiencies had a strong negative and significant association with ICT adoption, utilisation, and the intensity of use of connectivity technologies. Also ICT training was significantly and positively related to all three ICT measures. Firm competitiveness and access to ICT infrastructure and openness to external sources of information also significantly affected ICT adoption and connectivity. Further, Forth and Mason (2004) found that the extent of ICT adoption, intensity of computer use, and 
intensity of use of connectivity technologies would positively and significantly determine firm performance. In contrast, ICT skills gap and ICT training provision were not found to have any statistically significant effects on sales performance.

For Malaysia, the necessary infrastructure and environment for the development of ICT was in place during the Seventh Malaysia Plan period to enable the rapid movement into the Information Age. The National Information Technology Agenda (NITA), formulated in 1996, provided the framework for the orderly development of the country into an information and knowledge-based

- society by 2020 . The Seventh Malaysia Plan period saw a rapid growth in ICT utilisation. Investment in ICT expanded at a rate of $9.2 \%$ per annum from RM3.8 billion in 1995 to RM5.9 billion in 2000, due to the increasing awareness of Malaysians on the importance of production, diffusion, and - utilisation of knowledge and information for improving competitiveness and overall economic performance (Malaysia, 2001).

In terms of the small and medium enterprises (SMEs), the government has pledged to lead the country into the information age by giving technology-related financial grants or assistance schemes. Government agencies such as Small and Medium Enterprise Development Corporation (SMIDEC), Malaysia External Trade Development Corporation (MATRADE), Malaysia Industrial Development Corporation Authority (MIDA), the Malaysia Technology Development Corporation (MTDC), and the Ministry of Entrepreneur provide grants and incentives for SME development in various forms.

However, the report by the Small and Medium Industry (SMI) Association of Malaysia (2003) shows that ICT implementation among local SMEs is still at a very basic level since about $90.0 \%$ of the 100,000 local SMEs use PCs for simple operations such as basic accounting, financial data, and word processing. Only about $30.0 \%$ of local SMEs have some kind of web presence and use technology in their daily operation. Hussin and Mohamed Noor (2003) argued that the prospect of e-commerce in SMEs is bright. With the right adoption strategy, e- commerce can bring competitive advantages to SMEs. The factors such as IT expertise, good advice and support, CEO enthusiasm towards adoption, and the right marketing strategy could make e-commerce implementations more successful. This optimistic argument was also supported by Ab. Razak (2002) in his study conducted in 1999 and 2001 on 811 Malaysian SMEs. He found that SMEs in Malaysia were beginning to take up Internet-based business as about 55\% had Internet access in 1999 and the percentage increased to $77 \%$ in 2000 . At the same time, about $50 \%$ of the SMEs had websites for online advertising and $43 \%$ took orders on the Internet.

From the gender perspective, United Nations (2000) reported that one important impediment in the fuller realisation of the potential of ICT for development was the continued inadequacy of women's involvement and participation. According to available data, women account for $38 \%$ of users in the United States, 25\% in Brazil, 17\% in Japan and South Africa, $16 \%$ in the Russian Federation, $7 \%$ in China, and $4 \%$ in the Arab States.

Data of ICT usage by gender in Malaysia so far is not available. The number of PCs installed however rose dramatically from 610,000 in 1995 to 2.2 million in 2000 . The number PCs per 1000 population also rose from $29.6 \%$ in 1995 to $95.7 \%$ in 2000. In the business sector, the government has put an effort to enhance women involvement by giving them training in business-related areas such as marketing, accounting, and budgeting. In addition, the government has also placed emphasis on the utilisation of ICT in business in order to encourage women's participation in the global market.

The aim of this paper is to examine the status of the ICT adoption and utilisation among women entrepreneurs, to analyse factors that contribute to computer utilisation, and to analyse the impact of ICT adoption on firm performance. The analysis is based on 200 women entrepreneurs surveyed in 2004, who are involved in various business activities in that area. They represent several types of industries that are particularly important in that area. This paper is organised into five sections. Section two highlights background 
of the data; section three discusses the theoretical framework and model specification; section four analyses the results from the estimation of the models; and lastly section five highlights the conclusions and some policy implications.

\section{SOURCE AND BACKGROUND OF THE DATA}

The sample in this study is chosen at random, based on representative industries at the national level. In 2004, the services sector in total, contributed $41.1 \%$ towards the Malaysian gross domestic product (GDP), followed by the manufacturing sector $(35.8 \%)$. These two sectors also form a major contribution to employment with the percentage contribution of $46.4 \%$ and $25.4 \%$, respectively. In terms of women employment, $22.3 \%$ came from the service sector and $27.3 \%$ from the manufacturing sector. Within the service sector, the wholesales and retail trade formed the major contributor to the GDP and employment at $15.0 \%$ and $16.5 \%$, respectively. Taking this into account, the majority of the firms in this study are from the service sector. The 200 respondents,

who are the owner of the firms in the Klang Valley were chosen at random and the information was gathered from them through interview by appointed enumerators. With the effort from our enumerators, the study had managed to get a $100 \%$ response rate. Even though the sample size is quite small, it does not affect the validity of the analysis since the majority of the industries in this area are homogenous.

This section discusses the respondents' background, business information and status of ICT adoption and utilisation. The majority of the respondents interviewed are in the productive group where $12.0 \%$ are between 21-30 years old, $43.0 \%$ are between $31-40$ years old and $34.5 \%$ are between $41-50$ years old. There are only about $8.5 \%$ of the respondents who are 50 years old and $2.0 \%$ of them are below 21 years old. In terms of their marital status, $72.0 \%$ are married, $24.0 \%$ are single, and $4.0 \%$ are widows. The sample comprises of $46.5 \%$ Malays, $37.0 \%$ Chinese, and $16.5 \%$ Indians (Table 1).

The percentage of the respondents with diploma and degree level of education is quite high at about $40.5 \%$ and their percentage with primary and lower secondary level of education are quite low. Viewing from a positive relationship between knowledge and educational attainment, the involvement of more educated individuals in business activities may contribute positively to their success.

\section{Table 1}

\section{Educational Level of Respondents}

\begin{tabular}{lcc} 
Educational Level & Frequency & Percentage (\%) \\
\hline Primary/Lower Secondary & 5 & 2.5 \\
Upper Secondary & 62 & 31.0 \\
HSC & 52 & 26.0 \\
Diploma & 48 & 24.0 \\
Degree holders & 33 & 16.5 \\
Total & 200 & 100.0 \\
\hline Types of Business & Frequency & Percentage (\%) \\
\hline Retail business & 141 & 70.5 \\
Manufacturing & 28 & 14.0 \\
Services & 17 & 8.5 \\
Tourism & 7 & 3.5 \\
Internet/ICT & 7 & 3.5 \\
Total & 200 & 100.0 \\
\hline
\end{tabular}

Source: Field survey, 2004 
The majority of the respondents $(84.0 \%)$ have been operating their businesses for about 510 years. The detail distribution shows that their percentage with 1-5 years involvement are quite high at $52.0 \%$, while the distribution of others is $32.0 \%$ operating for $6-10$ years, $7.5 \%$ for 11 15 years, $5.5 \%$ for $16-20$ years, and only $3.0 \%$ with more than 20 years of involvement. The short period of involvement may affect women's achievement in their business undertakings.

Women in the sample are involved in varies types of business activities that can be categorised into five main groups. About $70.5 \%$ of respondents are involved in retail business - selling accessories, shoes, flower, and etc; followed by $14.0 \%$ in manufacturing mainly in the food and beverage industry; $8.5 \%$ in services like saloon and cosmetics; $3.5 \%$ in tourism; and $3.5 \%$ in Internet/ICT. The skewed involvement in a more traditional activity like retail business - reflects their reduced capability in penetrating into better potential activities like manufacturing and tourism. In a study by Abu Bakar and Haji Idris (2001), they found that women hesitate to be involved in more modern business activities due to lack of experience, shortage of funds, and the fear of high risk. The sample comprises of - 54.5\% micro sized enterprises ( $<5$ employees), $44.5 \%$ small scale enterprises (5-50 employees), $0.5 \%$ medium scale (51-150 employees), and $0.5 \%$ large scale ( $>150$ employees). When the value of annual sales is used to define firm size, it was shown that $55.5 \%$ of the enterprises are micro (<RM250 thousand) and $44.5 \%$ are small (>RM250 thousand-RM10 million).

\section{STATUS OF ICT ADOPTION AND UTILISATION}

The discussion of ICT utilisation and adoption can be divided into three main groups. Firstly, the ICT usage such as Internet uses, phones, number of computers, and Internet speed. Secondly, factors that affect ICT usage such as pricing, technical training, human capital, and relevance of computer to the company, and thirdly, the advanced application of technology, such as e-commerce and industrial information technology.

Firm performance can be improved through ICT support, which will speed up and lessen the cost of communication activities and the process of document exchange. To realise this, ICT workers are particularly important. However, the study found that more than half of the respondents $(59.5 \%)$ do not employ any ICT workers, $37.5 \%$ employ 1-3 ICT workers, $2.5 \%$ employ $4-5$, only one respondent or $0.5 \%$ employ more than 5 . In consequence, the majority of the enterprises $(69.5 \%)$ under study have not sent their workers to ICT training in the last 5 years. Among them who have sent their workers to ICT training, about $12.0 \%$ have sent only one worker, $11.5 \%$ have sent two workers, $5.0 \%$ have sent three workers, and $1.5 \%$ and $0.5 \%$ have sent four and six workers respectively. The less emphasis on worker training reflects less awareness of the respondents on the importance of training in relation to their performance.

In the era of globalisation, communication networks like video teleconferencing, e-mail, and hand phone technologies are becoming more important tools in running a business. Through this technology, entrepreneurs will be able to communicate quickly with their workers wherever they are and market their products more efficiently. The products can be advertised and reach the customer more easily. This process will help the entrepreneurs to increase their volume of sales and profit.

However, only $29.0 \%$ of the respondents have their own website. It seems that many businesswomen do not have the initiative to use modern marketing channels in selling their products. The study also found that there are only two main communication networks that are normally used by the majority of firms, i.e. hand phone $(77.0 \%)$ and cell phone $(76.0 \%)$.

Computer technology, multimedia, and Internet are the main support tools that contribute to the success of businesses within the digital economy. The number of computers owned and used by the company will determine the ability to produce. The study found that $14.0 \%$ of the enterprises interviewed do not own any computer. Among them who own the computer, only a small 
number of computers are owned, i.e. $81.5 \%$ have between one and five units, $5.0 \%$ between six and 10 units, and only $2.5 \%$ have more than 10 units of computers.

The study showed that $85.0 \%$ of the firms use Microsoft Office, $48.0 \%$ use UBS accounting system, $46.0 \%$ use stock control software, and $34.0 \%$ use human resource management (HRM) software. From the respondents' perspective, $43.5 \%$ think that their level of computer utilisation is still low and $40.0 \%$ think that they are at the medium level. Table 2 presents the computer application by the firms under study. It is surprising to find that $8.5 \%$ of the firms never use the Internet in running their business despite

the fact that they own computers. The percentage of the respondents who do not use computers in their internal networking, production, accounting, and management activities are also quite high at

\begin{tabular}{lccccc}
\multicolumn{5}{c}{ Table 2 } \\
Level of Computer Application \\
\hline Level of usage & Internet & Internal networking & Production & Accounting & Management \\
\hline Migh & 12.0 & 2.5 & 2.5 & 4.5 & 6.5 \\
Medium high & 17.5 & 12.5 & 14.5 & 22.0 & 29.0 \\
Medium low & 15.5 & 13.0 & 11.5 & 12.0 & 7.0 \\
Low & 22.0 & 26.5 & 29.5 & 29.0 & 22.0 \\
Too Low & 24.5 & 25.5 & 25.0 & 20.5 & 22.5 \\
Never use & 8.5 & 20.5 & 17.0 & 12.0 & 13.0 \\
Total & 100.0 & 100.0 & 100.0 & 100.0 & 100.0 \\
\hline
\end{tabular}

$20.5 \%, 17.0 \%, 12.0 \%$, and $13.0 \%$ respectively. This reflects the lack of planning, meaning to say that some of them buy computers but do not use them perhaps due to skill unavailability to operate them. In other circumstances, they may not need computers or do not know the importance of using computers in their daily business activities.

Another important aspect that is related to ICT is basic computer knowledge among the workers. In these days workers must be equipped with at least basic computer knowledge to be more efficient or have a higher competitive edge. Nowadays people are trying to minimize paper usage in placing order, but just communicate through e-mail. The Internet usage, for example, provides many useful information regarding products, market and technology. Table 3 shows the basic computer knowledge possessed by the respondents.

Table 3

Entrepreneurs' Computer Knowledge

Types of knowledge

Know how to use computer/Internet

A little understanding about Internet

Always use Internet

Know nothing about computer

Always use online activity to serve market opportunity

Use online activity to serve information
Percentage $(\%)$

\section{5}

44.0

42.5

2.5

71.0

71.5 


\section{(continued)}

\begin{tabular}{ll}
\hline Serve advertisement through website & 64.5 \\
Use e-mail to contact customer & 45.0 \\
Use e-mail to contact supplier & 73.5 \\
Use internet for banking transaction & 61.0 \\
Use firm's website to take order from customer & 23.0 \\
Promote product through website & 24.0
\end{tabular}

Source: Field Survey, 2004

From the above table, it is shown that the majority of the respondents $(91.5 \%)$ know how to use the computer or Internet. In fact, $68.0 \%$ of them have attended computer training. Thus, the percentage of computer illiteracy among women entrepreneurs under study are only $8.5 \%$. Even though the percentage of computer literacy and having the basic knowledge among the women entrepreneurs is quite high, the majority of them do not use the knowledge to build up the website to improve their business. The study found that only $23.0 \%$ of the respondents use a website to take orders from customers and - $24.0 \%$ of the respondents use it to promote their products. Furthermore, the study also found that the majority of the respondents do not have any allocation to buy computer or train their staff in ICT knowledge.

\section{MODEL SPECIFICATION}

In order to achieve the main objectives of this paper, three approaches were adopted i.e. logistic regression model to look at the determinant of computer usage, Spearman Correlation to look at the relationship between ICT utilisation and firm performance, and multiple regression models to examine the effect of computer adoption and utilisation on firm performance.

\section{Logistic Regression}

Logistic distribution function (Gujarati, 1995) can be written as,

$$
P_{i}=\frac{1}{1+e^{-Z}}
$$

where

$$
Z_{i}=\beta_{1}+\beta_{2} X_{i}
$$

and

$$
1-P=\frac{1}{1+e^{z}}
$$

Therefore,

$$
\frac{P_{i}}{1-P_{i}}=\frac{1+e^{Z}}{1+e^{-Z}}
$$

Taking natural logarithm of equation (3), we obtain,

$$
L_{i}=\ln \left(\frac{P_{i}}{1-P_{i}}\right)=Z_{i}=\beta_{1}+\beta_{2} X_{i}
$$

Equation (4) is called the logit model where:

$\mathrm{L}_{\mathrm{i}}$ is the probability of the occurrence of certain events. $L$ is the $\log$ of odd ratio, is not only linear in $\mathrm{X}$ but also linear in the parameter. In order to estimate the vector of parameter $\beta$ the ordinary least square (OLS) cannot be applied because the dependent variable in the equation is a dichotomous observation, which is not normally distributed. Moreover, in this case the OLS does not satisfy the condition $0 \leq P_{i} \leq 1$. Thus, the maximum likelihood method can be applied here as a suitable estimation technique. The estimation model is as follows, 
$C U=\beta_{10}+\beta_{11} E D U+\beta_{12} P E+\beta_{13} F Z$

$+\beta_{14} B A+\mu_{1}$

\section{Multiple Regression Model}

To examine the impact of ICT utilisation on firm performance, the analysis is based on the CobbDouglas production function containing annual total sales (Q) as the dependent variable and physical capital (K), employment (L), and ICT utifisation related variables $(\mathrm{Z})$ as independent ariables.

$Q=A K^{\alpha} L^{\beta} Z^{\gamma}$

aking natural the logarithm of equation (6) we obtain,

$\ln Q=\ln (a)+\alpha \ln K+\beta \ln L+\gamma \ln Z$
Equation (7) represents the basic model for our analysis of impact of ICT on firm performance (total sales).

\section{Estimation Model}

Therefore, the estimation model formulated is as follows:

$$
\begin{aligned}
& J=\beta_{20}+\beta_{21} \ln K+\beta_{22} \ln L+\beta_{23} E D U \\
& +\beta_{24} B A+\beta_{23} F Z+\beta_{26} I C W T \\
& +\beta_{27} I N T L O W+\beta_{28} I N T H I G H \\
& +\beta_{29} N E T W L O W+\beta_{210} N E T W H I G H \\
& +\beta_{211} \text { PRODLOW }+\beta_{212} \text { PRODHIGH } \\
& +\beta_{213} \text { ACCTLOW }+\beta_{214} \text { ACCTHIGH } \\
& +\beta_{215} \text { MANLOW }+\beta_{215} \text { MANHIGH }+\mu_{2}
\end{aligned}
$$

The definitions of the variables for equation (5) and (8) are presented in Table 4.

\section{Table 4}

\section{Definition of the Variables}

Variables

$\mathrm{CU}$

EDU

$\mathrm{PE}$

FZ

BA

$\mathrm{J}$

$\mathrm{K}$

$\mathrm{L}$

ICTW

INTLOW

INTHIGH

\section{Definition}

A dummy variable coded 1 if firm use computer, 0 otherwise

A dummy variable coded 1 if entrepreneur level of education is secondary, 0 otherwise (tertiary)

Year of establishment of firms owned by respondents

A dummy variable coded 1 if number of employment $>5,0$ otherwise

A dummy variable coded 1 if business activity is manufacturing related, 0 otherwise

Logarithm of value of sales in 2004 (RM)

Value of physical capital (RM)

Number of workers employed by firms

Number of ICT workers owned by firm

A dummy variable coded 1 if firm level of internet usage is low (when the respondent answer 1,2, or 3), 0 otherwise

A dummy variable coded 1 if firm level of internet usage is high (when the respondent answer 4 or 5), 0 otherwise 
(continued)

\begin{tabular}{cl}
\hline NETWLOW & $\begin{array}{l}\text { A dummy variable coded } 1 \text { if level of internal network usage is low (when the } \\
\text { respondent answer 1,2, or 3), } 0 \text { otherwise }\end{array}$ \\
\hline NETHIGH & $\begin{array}{l}\text { A dummy variable coded } 1 \text { if level of internal network usage is high (when the } \\
\text { respondent answer } 4 \text { or 5), } 0 \text { otherwise }\end{array}$ \\
\hline PRODLOW & $\begin{array}{l}\text { A dummy variable coded } 1 \text { if level of computer usage in the production is low } \\
\text { (when the respondent answer 1,2, or 3), 0 otherwise }\end{array}$ \\
\hline PRODHIGH & $\begin{array}{l}\text { A dummy variable coded } 1 \text { if level of computer usage in the production is high } \\
\text { (when the respondent answer 4 or 5), 0 otherwise }\end{array}$ \\
\hline ACCTLOW & $\begin{array}{l}\text { A dummy variable coded } 1 \text { if level of computer usage in accounting is low (when } \\
\text { the respondent answer 1,2, or 3), 0 otherwise }\end{array}$ \\
\hline MANAGLOW & $\begin{array}{l}\text { A dummy variable coded } 1 \text { if level of computer usage in accounting is high } \\
\text { (when the respondent answer 4 or 5), } 0 \text { otherwise }\end{array}$ \\
\hline MANAGHIGH & $\begin{array}{l}\text { A dummy variable coded } 1 \text { if level of computer usage in management is low } \\
\text { (when the respondent answer 1,2, or 3), 0 otherwise }\end{array}$ \\
\hline
\end{tabular}

This study had established four main hypotheses to be tested:

1. The entrepreneurs' level of education has a significant positive impact on computer utilisation and firm performance.

2. Bigger firms would be more likely to use ICT and gain higher performance.
3. The service sector uses computer more intensively as compared to the manufacturing sector and it has better performance.

4. An intensive use of ICT contributes a significant positive impact on firm performance.

Table 5

Determinants of Computer Usage

\begin{tabular}{lcccc}
\hline Variable & Coefficient (B) & Standard Error & Wald & Exp (B) \\
\hline Constant & $1.692(0.000)^{* * *}$ & 0.302 & 31.447 & 5.429 \\
Education & $0.875(0.043)^{* *}$ & 0.432 & 4.105 & 0.417 \\
Period of Establishment & $2.146(0.000)^{* * *}$ & 0.771 & 7.036 & 6.864 \\
Firm size & $1.535(0.010)^{* * *}$ & 0.595 & 6.659 & 4.640 \\
Business activity & $0.166(0.845)$ & 0.847 & 0.038 & 1.181 \\
-2log likelihood & 148.113 & & & \\
Cox and Snell R & 0.667 & & &
\end{tabular}

Note: $* * *$ significant at $1 \%$ significance level

** $\quad$ significant at $5 \%$ significance level 


\section{RESULTS}

\section{Determinant of Computer Usage}

The results of estimation of the logistic regression (equation 7) are presented in Table 5. There are three significant factors that determine the utilisation of computer by firms. More educated entrepreneurs are more likely to use the computer as compared to less educated entrepreneurs. Firms that have been established longer were also found to be more likely to use the computer. This implies that firms have developed their capacity over time and may become stronger or more established the longer they are in operation.

- The other significant factor is firm size, Which shows that the bigger firms are, the more likely they are to use the computer in their rganisation. This finding can be related to the Stronger financial capability of the bigger firms. The big firms may enjoy higher turnover that allows them to use modern techniques that are in line with their product design and higher product quality.

\section{Impact of ICT on Firm Performance}

A Firm's performance can be assessed from its percentage of total sales, export, profit, and product diversification (Forth \& Mason 2004). Two ICT indicators were used in analysing their impact on firm performance, i.e. number of ICT workers and level of ICT utilisation in a firm. The study also looked at other variables that affected firm performance like entrepreneur educational achievement, firm size, types of business - activities, and period of firm establishment. The analysis adopted two approaches in looking at the retationship between ICT and firm performance. In the first approach the Spearman Correlation between various firm performance and ICT indicators was used. The second approach involved multiple regressions.

Table 6 shows the Spearman Correlation between firm performance and level of ICT usage in the firms surveyed. It is shown that entrepreneur level of education does not significantly determine the firm performance indicators except the percentage of export, which is positively significant. This implies that when the level of education of the entrepreneur is higher, the higher will be the percentage of their output that can be exported. This maybe due to better knowledge about the foreign market or a more established business context. Firm size plays a very important role in determining firm performance since the relationships are all positively significant, except for the number of product variation. Larger firms may benefit from economies of scale in production, and market share domestically or in the international market.

The relationship between firm performance and the length of period of firm establishment are all positively significant. Firms that are longer in operation may benefit from many advantages like business context and technological information that may help to drive their business. It was found that business activities that are related to services manage to achieve better performance when compared to manufacturing related activities. The study uses six indicators of ICT usage, i.e. the number of ICT workers, level of Internet usage, level of internal network, level of computer usage in production, accounting, and management. Of all the variables listed, the number of ICT workers has a significant positive relationship only with the percentage export. Level of Internet usage has a significant positive relationship with percentage export and profit. On the other hand, the level of internal network and computer usage in the production process and accounting have positively significant relationships with value of sales, percentage export, and profit. However, computer usage in management is not significant except with profit return.

The model of multiple regressions is used to further examine the determinant factors of total sales. Three regressions were estimated, which included 1) capital and labour as two main factors of production; 2) entrepreneur level of education, types of activity, and firm size besides capital and labour; 3) ICT usage indicators besides variables in equation 2 . The results are presented in Table 7.

The results show that capital and labour are the main determinant factors of total sales. The coefficients of these two variables are significant at $1 \%$ significance level in all equations. The inclusion of other variables does not alter the significance 


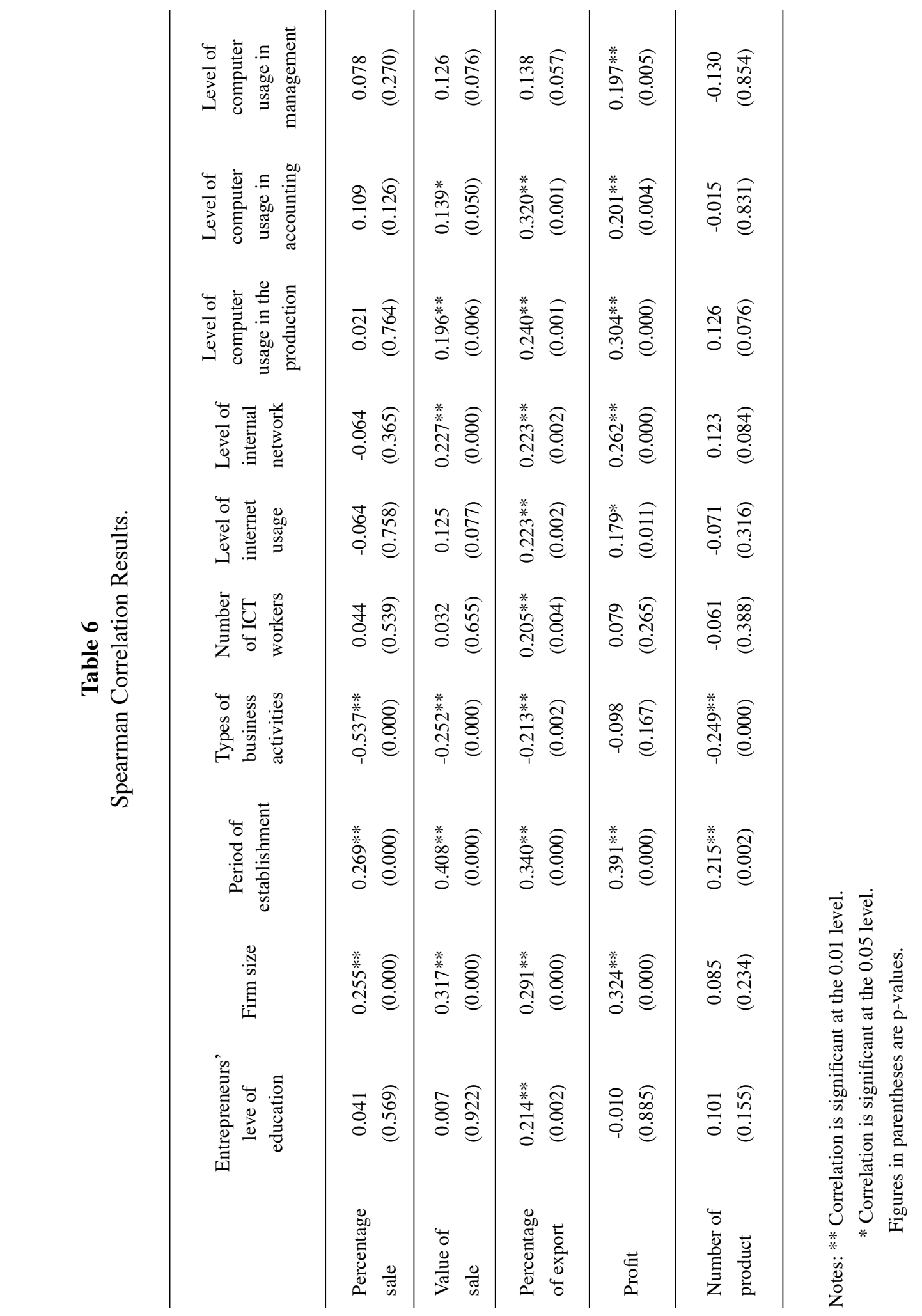


level of these two variables. The service related activities are shown to benefit higher total sales as compared to the manufacturing related activities. However, when ICT indicators were added in the regression, this differential is more significant. The number of ICT workers employed within the firms also positively and significantly determines total sales. The higher level of ICT usage, which is measured by Internet usage, internal network production, production, and accounting would significantly give higher benefits in terms of total sales as compared to their counterparts that do not use these facilities. However, when the level of computer usage is low, it does not significantly differentiate total sales with the firms that do not use computer at all, except for the internal network. The use of computer in management does not contribute significantly to total sales.

Table 7

Results of regression estimates

\begin{tabular}{|c|c|c|c|}
\hline Variable & 1 & 2 & 3 \\
\hline Intercept & $10.795(45.790)^{* * *}$ & $10.864(43.273)^{* * *}$ & $10.656(29.377)^{* * *}$ \\
\hline K & $0.068(3.365)^{* * *}$ & $0.064(3.131)^{* * *}$ & $0.060(2.805)^{* * *}$ \\
\hline & $0.577(8.421)^{* * *}$ & $0.607(5.412)^{* * *}$ & $0.618(5.224)^{* * *}$ \\
\hline DU & & $-0.077(-0.643)$ & $0.019(0.156)$ \\
\hline A & & $-0.381(-2.157) * *$ & $0.002(0.008)$ \\
\hline $\mathrm{Z}$ & & $0.217(2.426)^{* *}$ & $0.227(2.421)^{* *}$ \\
\hline TW & & & $0.073(1.890)^{*}$ \\
\hline NTLOW & & & $0.045(1.142)$ \\
\hline NTHIGH & & & $0.090(2.292)^{* *}$ \\
\hline NETLOW & & & $0.038(2.125)^{* *}$ \\
\hline NETHIGH & & & $0.449(2.524)^{* *}$ \\
\hline ODLOW & & & $0.287(0.890)$ \\
\hline PRODHIGH & & & $0.006(2.019)^{* *}$ \\
\hline CCTLOW & & & $-0.006(-0.019)$ \\
\hline ACCTHIGH & & & $0.083(3.303)^{* * *}$ \\
\hline MANLOW & & & $-0.018(-0.068)$ \\
\hline MANHIGH & & & $0.021(0.488)$ \\
\hline $\mathrm{R}^{2}$ & 0.339 & 0.360 & 0.401 \\
\hline $\mathbf{N}$ & 200 & 200 & 200 \\
\hline
\end{tabular}

Note: $* * *$ significant at $1 \%$ significance level.

** significant at 5\% significance level.

* significant at $10 \%$ significance level. 


\section{CONCLUSIONS AND POLICY IMPLICATION}

The results from the study show that computer utilisation by women entrepreneurs will depend significantly on their level of education, firm size, and period of establishment. Firm size and ICT related workers also significantly determine total sales. The relationship between ICT utilisation and firm performance indicators is significantly positive, especially in the production and internal network. These two activities are particularly important especially in the service related activities, where the majority of respondents are involved. The results from the estimation of regression show that all ICT indicators, i.e. ICT workers and high computer usage all significantly determine total sales, except for computer usage in management. In fact, for the internal network, the low usage also contributes significantly to firm total sales.

The study suggests that women entrepreneurs should expand their production capacity in order to perform better. Firms also must employ more ICT workers or give more ICT related training to workers. In the study, there were - very few firms who do allocate their expenditure on worker training. The level of ICT utilisation also must be increased as it helps to increase sales and also other performance indicators like profit and export. A low level of ICT utilisation may not help the firm to prosper further, because it does not give enough impact on performance. Therefore, in order to benefit from ICT, the firm must be seriously involved in ICT expenditure, like buying ICT facilities and equip their organisation with skilled workers.

Based entirely on our study, we would like to conclude our findings by iterating that further research must include more comprehensive measures of ICT adoption and utilisation in order to look at its impact on firm performance. Further research may incorporate other variables like location, pricing, infrastructure, firm culture, and regulation. A wider sector coverage and larger sample size may enable the researcher to make a comparative analysis among the sectors involved regarding ICT utilisation and firm performance.

\section{REFERENCES}

Bresnaham, T. E., Brynjolfsson, \& Hitt, L. (2002). Information technology, workplace organisation and the demand for skilled labour: Firm level evidence. Quarterly Journal of Economics, 117, 339-376.

Forth, J., \& Mason, G. (2004). Information and communication technology (ICT) adoption and utilisation, skill constraint and firm level performance: Evidence from UK benchmarking survey. NIESR Discussion Paper No. 234.

Gujarati, D. N. (1995). Basic econometrics. New York: McGraw-Hill International Editions.

Helpman, E., \& Trajtenberg, M. (1998). A time to sow and a time to reap: Growth based on general purpose technologies. In E. Helpman (Ed) General Purpose Technologies and Economic Growth. Cambridge: Mass MIT Press.

Husnayati, Hussin., \& Rafidah, Mohamed Noor (2003). A review of factors affecting the adoption of e-commerce amongst Malaysian SEMs. Paper presented at National Seminar on Electronic Commerce. Sunway Lagoon Resort Hotel, $7^{\text {th }}$ Ontober.

Malaysia. (2001). Eighth Malaysia Plan 20012005. Kuala Lumpur: Percetakan Nasional Malaysia Berhad.

Mazlan, Ab. Razak (2002). Development of e-commerce in Malaysia: The national e-commerce strategic direction. Paper presented at E-business National Conference for Small and Medium Industries (SMIs), 21-22 October.

Norlaila, Abu Bakar., \& Nor Aini, Haji Idris (2001). Kesan dan cabaran teknologi terhadap keupayaan bersaing di kalangan peniaga wanita. Laporan akhir penyelidikan, Fakulti Ekonomi, UKM. 
Pippa, N. (2000). The worldwide digital divide: Information poverty, the Internet and development. Paper presented for the Annual Meeting of the Political Studies Asssociation of the UK, London School of Economic and Political Science, 10-13 April.
SMI Association of Malaysia. (2003). SMI Business Directory.

United Nations. (2000). Development and international cooperation in the twenty-first century: The role of information technology in the context of a knowledge-based global economy. New York: Economic and Social Council. 